\title{
Factors hindering health care delivery in nomadic communities: a cross-sectional study in Timbuktu, Mali
}

Moussa Sangare ${ }^{1,2^{*}}$, Yaya Ibrahim Coulibaly ${ }^{1}$, Siaka Yamoussa Coulibaly ${ }^{1}$, Housseini Dolo ${ }^{1}$, Abdoul Fatao Diabate ${ }^{1}$, Kueshivi Midodji Atsou', Abdoul Ag Souleymane', Youssouf Ag Rissa', Dada Wallet Moussa', Fadimata Wallet Abdallah', Massitan Dembele ${ }^{3}$, Mahamadou Traore ${ }^{3}$, Tieman Diarra ${ }^{4}$, William R. Brieger ${ }^{5}$, Sekou Fantamady Traore ${ }^{1}$, Seydou Doumbia ${ }^{1}$ and Samba Diop ${ }^{1}$

\begin{abstract}
Background: In Mali, nomadic populations are spread over one third of the territory. Their lifestyle, characterized by constant mobility, excludes them from, or at best places them at the edge of, health delivery services. This study aimed to describe nomadic populations' characteristics, determine their perception on the current health services, and identify issues associated with community-based health interventions.

Methods: To develop a better health policy and strategic approaches adapted to nomadic populations, we conducted a cross-sectional study in the region of Timbuktu to describe the difficulties in accessing health services. The study consisted in administering questionnaires to community members in the communes of Ber and Gossi, in the Timbuktu region, to understand their perceptions of health services delivery in their settings.

Results: We interviewed 520 individuals, all members of the nomadic communities of the two study communes. Their median age was 38 years old with extremes ranging from 18 to 86 years old. Their main activities were livestock breeding (27\%), housekeeping (26.4\%), local trading (11\%), farming (6\%) and artisans (5.5\%). The average distance to the local health center was $40.94 \mathrm{~km}$ and $23.19 \mathrm{~km}$ respectively in Gossi and Ber. In terms of barriers to access to health care, participants complained mainly about the transportation options (79.4\%), the quality of provided services (39.2\%) and the high cost of available health services (35.7\%). Additionally, more than a quarter of our participants stated that they would not allow themselves to be examined by a health care worker of the opposite gender.
\end{abstract}

Conclusion: This study shows that nomadic populations do not have access to community-based health interventions. A number of factors were revealed to be important barriers per these communities' perception including the quality of services, poverty, lifestyle, gender and current health policy strategies in the region. To be successful, future interventions should take these factors into account by adapting policies and methods.

Keywords: Nomadic, Access, Healthcare, Delivery, Timbuktu, Mali

\footnotetext{
* Correspondence: mbsangare@icermali.org

'Mali International Center for Excellence in Research (ICER), University of Sciences, Techniques, and Technologies of Bamako (USTTB), Bamako, Mali ${ }^{2}$ Interdisciplinary School of Health Sciences | Faculty of Health Sciences, University of Ottawa, 75, av. Laurier Est, Ottawa ON K1N 6N5, Canada Full list of author information is available at the end of the article
}

(c) The Author(s). 2021 Open Access This article is licensed under a Creative Commons Attribution 4.0 International License, which permits use, sharing, adaptation, distribution and reproduction in any medium or format, as long as you give appropriate credit to the original author(s) and the source, provide a link to the Creative Commons licence, and indicate if changes were made. The images or other third party material in this article are included in the article's Creative Commons licence, unless indicated otherwise in a credit line to the material. If material is not included in the article's Creative Commons licence and your intended use is not permitted by statutory regulation or exceeds the permitted use, you will need to obtain permission directly from the copyright holder. To view a copy of this licence, visit http://creativecommons.org/licenses/by/4.0/ The Creative Commons Public Domain Dedication waiver (http://creativecommons.org/publicdomain/zero/1.0/) applies to the data made available in this article, unless otherwise stated in a credit line to the data. 


\section{Background}

In rural areas of Mali, especially in the northern part of the country, local populations experience the highest infant mortality rates (191 per 1000 births). In other words, one out of five Malian children in these areas dies before reaching 5 years of age [1]. The distribution of health facilities throughout the country is disparate and based not only on demographics but also on politics and socio-economic aspects [2]. Indeed, health services and human resources are generally concentrated in the populated urban areas of the country. As an illustration, $57 \%$ of the medical doctors, $47 \%$ of the nurses and $64 \%$ of the midwives are currently working in the capital city, Bamako [3].

On the fringe of the Sahara desert in the Sahel region of West Africa, $65 \%$ of Mali's land is desert or semidesert [4]. Wealth and natural resources are unequally distributed across the country. Those living in the northern regions of the country suffer from recurring periods of drought and widespread food shortages $[5,6]$.

An estimated $50-100$ million people or $30-60 \%$ of the world's nomadic and semi-nomadic people live in Africa. Nomadism is common in many Sub-Saharan African countries including Mali [7-9]. Nomadic populations have less access to health services compared to the general population [10]. They are also disproportionately vulnerable to infectious diseases such as malaria, tuberculosis, Guinea worm disease, leishmaniasis, onchocerciasis, schistosomiasis, soil-transmitted helminthiases, brucellosis and trachoma [10].

Little is known on how to efficiently provide essential healthcare services to nomadic populations and those living in remote rural areas [11]. The constant mobility of nomadic populations excludes them, or at best places them at the edge of health delivery services. Nomadic community health workers (CHWs) recruitment, training and their support by the community constitute an additional challenge [12]. Preliminary data from this study showed that cultural and socio-economic factors such as gender, lifestyle, proximity and constant mobility with animals affect access to health interventions [13]. This study aimed to describe nomadic populations' characteristics and determine factors limiting nomads' access to current health services and identify accessibilityrelated health intervention issues among the nomads.

\section{Methods}

\section{Study setting}

The study was conducted in the Timbuktu region, in the commune of Ber, in the health district of Timbuktu and the commune of Gossi in the health district of Gourma Rharous, both of which are located at about $900 \mathrm{~km}$ from Bamako, the capital city of Mali [4].

\section{Study population}

The study was performed among Kel Tamasheq, Songhai, Arab, Fulani and Bozo people. The main lifestyle of these populations is pastoralism that requires a nomadic lifestyle for a significant part of the community. Nomadic populations settle in small groups of 25-35 people in a campsite for a relatively long period of time (20-30 days) and then move from one seasonal grazing area to another without specific directions. Movement is driven by the grazing. Each campsite is composed of around 3-5 families with 5 to 7 households each living in 4-6 tents around a leader who is usually the eldest family member. They settle with their animals around an oasis in transhumance between the northern and southern parts of the country depending on the season and availability of pasture for their animals. With these conditions and cultural values, nomads prefer not to stay in these communities due to the constant search for new pastures for livestock. They spend most of their time and effort caring for their animals. Therefore, it seems as if the welfare and the health of their animals is as important as their own wellbeing [14].

\section{Study design}

We conducted a cross-sectional study from January to March 2011 in the communes of Ber and Gossi by administrating a questionnaire to community members. In each commune, we went to the different villages and nomadic camps to interview people. When we arrived in a camp we explained the study and among the volunteers, 3 or 4 people were randomly selected. In the villages, from the list of families, 4 or 5 families were selected and 3 or 4 people from these families were selected as volunteers. It should be noted that in the study sites the size of the villages did not exceed 15-20 families. Only volunteers of 18 years of age and above who were able to give informed consent were included in the study.

\section{Sample size and statistical considerations}

The sample size has been estimated by using Epi Info software; assuming 95\% confidence level, power of 80 and $20 \%$ of no access in healthcare among the nomadic population. The level of significance was set at 0.05 (two-tailed). Data were analyzed using the statistical package for social sciences (SPSS) version 20.0 (https:// www.ibm.com/analytics/spss-statistics-software) and chisquare tests performed to compare proportion as appropriate. The graphs were generated by using GraphPad Prism 8 (https://www.graphpad.com). Missing data were not included in the analysis. The missing data that were not considered in the analysis because they were very few. Only four (4) subjects who did not complete the questionnaire so we decided not to consider the incomplete information of these subjects in the analysis. 
Data collection methods and instruments

A questionnaire was administrated to community members by well-trained investigators. The content of the questionnaire was related to health problems specific to the context of nomadic communities, such as the lack of medicines or the inadequacy of modern means of transport such as vehicles and ambulances. For example, pregnant women with complications during maternal labor and delivery are transported in carts pulled by donkeys.

\section{Questionnaire development}

For the questionnaire development (Additional file 1), we mainly focused on the study objectives to generate questions that could provide with accurate and complete information specific to the nomadic context of northern Mali. After the questionnaire development, it was reviewed by the senior researchers and then tested in Bamako during the simulation sessions. The shortcomings were considered before the actual field survey phase. The questionnaire development was done to get insight about nomads' access to and use of available health care based on health belief model theory [15]. It was entirely made up by the study investigators for the purpose of this study.

\section{Results}

We included a total of 520 participants in this study. The sex ratio of participants was 1.34 in favor of men with a median age of 38 [18-86] years. The $31-45$ years group was the most represented among the study population. Most of the participants were livestock breeders (22.88\%), housekeepers (20.77\%) and traders (8.46\%). Among them, livestock breeding, and housekeeping were the most frequent respectively for men and women (Table 1). Other occupations have been cited including craftsmanship, agriculture, civil servant and marabouts (8.27\%).

In both Ber and Gossi, $63 \%$ of those surveyed in this study were illiterate. The other types of education among the participants in both cities were literacy in the Arabic language or primary school level (respectively 19.04 and $10.96 \%$ of those surveyed in this study). In our study, most of the participants (65.38\%) were married, followed by single (11.73\%) and divorced (4.42\%). Approximately $11.92 \%$ of the participants did not wish to give their marital status (Table 1).

The distance to the healthcare facility was not excessive for $40 \%$ of our participants. With respect to cost, there was a huge difference between those who thought that health care costs were not too high $(48.08 \%)$, and those who thought it was too expensive (27.50\%). Most of participants $(45.38 \%)$ said that the quality of health
Table 1 Characteristics of the study population

\begin{tabular}{|c|c|c|c|}
\hline Characteristics & $\begin{array}{l}\text { Ber } \\
\text { n (\%) }\end{array}$ & $\begin{array}{l}\text { Gossi } \\
\text { n (\%) }\end{array}$ & $\begin{array}{l}\text { Overall } \\
\mathrm{N}(\%)\end{array}$ \\
\hline Male/Female (Ratio) & $164 / 95(1.72)$ & $134 / 127(1.05)$ & $298 / 222(1.34)$ \\
\hline Median age (min; max) & $38(18-86)$ & $38(18-86)$ & $38(18-86)$ \\
\hline \multicolumn{4}{|l|}{ Age-groups (in years) } \\
\hline $18-30$ & $107(41.31)$ & 75 (28.74) & $182(35)$ \\
\hline $31-45$ & 89 (34.36) & $101(38.7)$ & $190(36.54)$ \\
\hline$\geq 46$ & $63(24.32)$ & $85(32.57)$ & $148(28.46)$ \\
\hline Total & $259(100)$ & $261(100)$ & $520(100)$ \\
\hline \multicolumn{4}{|l|}{ Marital status } \\
\hline Single & $41(15.83)$ & $20(7.66)$ & $61(11.73)$ \\
\hline Divorced & $10(3.86)$ & $13(4.98)$ & $23(4.42)$ \\
\hline Married & 159 (61.39) & $181(69.35)$ & $340(65.38)$ \\
\hline Separated & $9(3.47)$ & $7(2.68)$ & $16(3.08)$ \\
\hline Widowed & $5(1.93)$ & $13(4.980$ & $18(3.46)$ \\
\hline Unknown & $35(13.51)$ & $27(10.34)$ & $62(11.92)$ \\
\hline Total & $259(100)$ & $261(100)$ & $520(100)$ \\
\hline \multicolumn{4}{|l|}{ Education } \\
\hline Kel Tamasheq alphabet & $0(0)$ & $4(1.53)$ & $4(0.77)$ \\
\hline College & $2(0.77)$ & $0(0)$ & $2(0.38)$ \\
\hline Arabia & $51(19.69)$ & $48(18.39)$ & $99(19.04)$ \\
\hline Primary school & $37(14.29)$ & $20(7.66)$ & $57(10.96)$ \\
\hline Illiterate & $145(55.98)$ & $187(71.65)$ & $332(63.85)$ \\
\hline Secondary & $18(6.95)$ & $2(0.77)$ & $20(93.85)$ \\
\hline University & $6(2.32)$ & $0(0)$ & $6(1.15)$ \\
\hline Total & $259(100)$ & $261(100)$ & $520(100)$ \\
\hline \multicolumn{4}{|l|}{ Main occupation } \\
\hline Livestock breeding & $50(19.31)$ & $69(26.44)$ & 119 (22.88) \\
\hline Trading & $35(13.51)$ & $9(3.45)$ & $44(8.46)$ \\
\hline Housekeepers & $41(15.83)$ & $67(25.67)$ & $108(20.77)$ \\
\hline Others & $36(13.90)$ & $7(2.68)$ & $43(8.27)$ \\
\hline Total & $259(100)$ & $261(100)$ & $520(100)$ \\
\hline
\end{tabular}

Others = craftsmanship, agriculture, civil servant, marabout;

$\min =$ minimum; $\max =$ maximum

care was not good while $30.19 \%$ thought it was good (Table 2).

Lack of resources (financial and mean of transportation) was an obstacle for $60.96 \%$ of participants. This rate was statistically significant compared to the rest of the participants $(14.62 \%)$ who said it was not. More than $63 \%$ of the study population had a monthly income less than $\$ 120$ US Dollars (Table 3).

The most common barriers to nomads' access to health services included healthcare cost, means of transportation, visits to traditional healers, unwillingness of opposite gender medical examination and distance to the health center. Healthcare cost, means of 
Table 2 Perception of the study population about some factors that decrease the medical centers frequentation (distance, cost, healthcare quality)

\begin{tabular}{lll}
\hline Most factors cited & $\mathbf{n}$ & $\mathbf{( \% )}$ \\
\hline Distance (very far) & 208 & 40.00 \\
No & 185 & 35.58 \\
Yes & 127 & 24.42 \\
No respondents & $\mathbf{5 2 0}$ & $\mathbf{1 0 0 . 0 0}$ \\
Total & & \\
Cost (very high) & 250 & 48.08 \\
No & 143 & 27.50 \\
Yes & 127 & 24.42 \\
No respondents & $\mathbf{5 2 0}$ & $\mathbf{1 0 0 . 0 0}$ \\
Total & & \\
Healthcare quality (good) & 236 & 45.38 \\
No & 157 & 30.19 \\
Yes & 127 & 24.42 \\
No respondents & $\mathbf{5 2 0}$ & $\mathbf{1 0 0 . 0 0}$ \\
Total & & \\
Lack of funding & 76 & 14.62 \\
No & 317 & 60.96 \\
Yes & 127 & 24.42 \\
No respondents & $\mathbf{5 2 0}$ & \\
Total & & $\mathbf{1 0 0 . 0 0}$ \\
\hline
\end{tabular}

transportation, and visit to traditional healers were the most frequent barriers reported (Fig. 1). Participants emphasized the lack of financial resources (60.96\%). Some of our participants lived in campsites located at an average distance of $40 \mathrm{~km}$ in Ber and $23.19 \mathrm{~km}$ in Gossi with an extreme of more than $70 \mathrm{~km}$ where there is no health facility. This distance is statistically higher in Ber than in Gossi (Mann-Whitney U test $p<0.0001$ ) (Fig. 2).

Approximately, $60 \%$ of our participants stated that they lacked the financial resources to regularly attend

Table 3 Average monthly income of respondents by gender

\begin{tabular}{llllll}
\hline $\begin{array}{l}\text { Average } \\
\text { monthly } \\
\text { income }\end{array}$ & Female & & & \multicolumn{2}{l}{ Male } \\
\cline { 2 - 3 } \begin{tabular}{lllll} 
in USD \\
\cline { 5 - 6 }
\end{tabular} & $\mathbf{n}$ & $\%$ & & $\mathbf{n}$ & $\%$ \\
\hline Unknown & 76 & 34.23 & & 46 & 15.44 \\
$<120$ & 137 & 61.71 & & 192 & 64.43 \\
$120-200$ & 6 & 2.70 & & 46 & 15.44 \\
$201-350$ & 2 & 0.90 & & 10 & 3.36 \\
$351-500$ & 1 & 0.45 & & 3 & 1.01 \\
$>500$ & 0 & 0 & 1 & $\mathbf{2 9 8}$ & $\mathbf{5 7 . 3 0}$ \\
\hline
\end{tabular}

USD United States Dollars

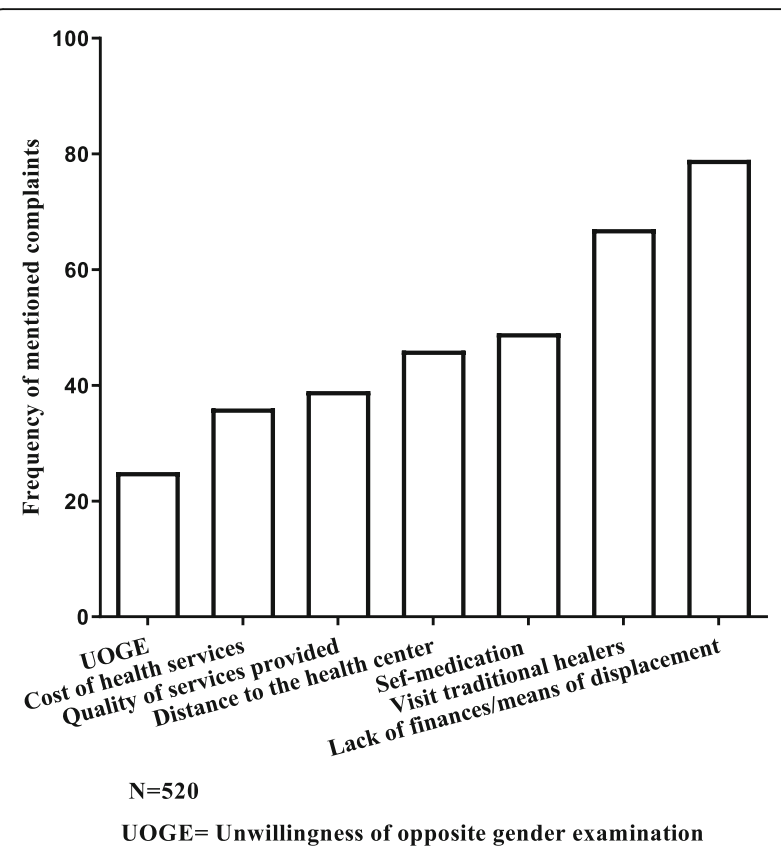

Fig. 1 Frequency of the most common barriers to nomads' access to health services mentioned by the respondents

health services (Fig. 3a). In addition, more than $77 \%$ of respondents said they would not accept being examined by an agent of the opposite gender (Fig. 3b).

\section{Discussion}

Most of the study population (47\%) were illiterate and mainly represented by the age group of 38-47. The reluctance of some older people to enroll their children in the formal education system may be due to a loss of confidence between the country's officials and their partners. There were more men among the study participants because the prevailing perception in these communities amongst women is that it is the men's responsibility to represent or to speak on behalf of the community. Also, in Tamasheq settings, women are inaccessible to visiting men, unwilling to speak to a stranger or a man who could become her husband because of customs and being Muslim (100\% of participants).

Tamasheq was the most widely-spoken local language (65\%). Tamasheq is the language of the Tuareg nomads in Mali and is the common point of a whole ethnic groups known as "Kel Tamasheq (meaning people of the Tamasheq language)". Most of them can read and write Arabic. They learn this language from an early age in order to read and write Quran later. Kel Tamasheq also have their own alphabet called "Tifinagh (meaning $\mathrm{Kel}$ Tamasheq alphabet). The linking with nomadic ancestral values is a key element that hinders social and health development in northern Mali. The standard of living is not very high hence; the society is based on a very strong 


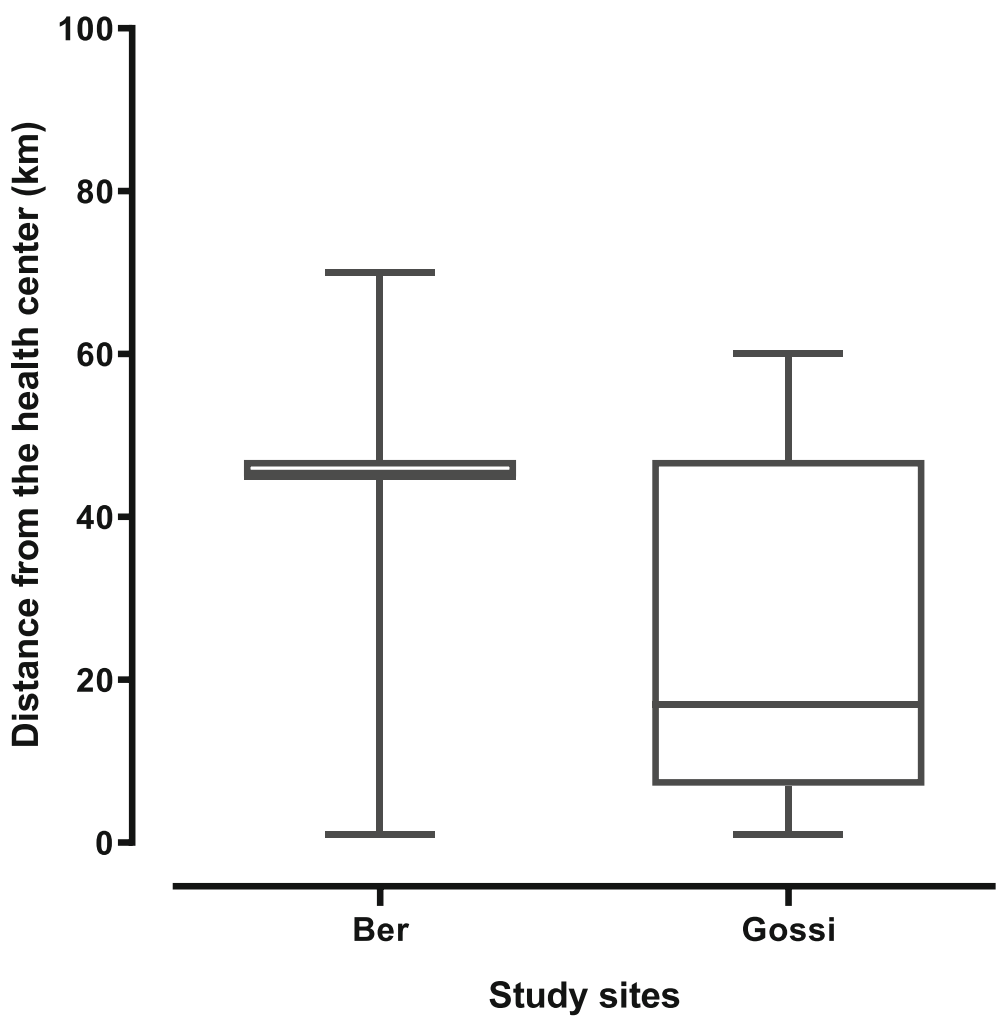

Fig. 2 Variation of the median distance between respondents' location and the closest health center per study site

tribal model and mutual assistance. When implementing public health interventions, the actors must take into account these factors for the success of the program [1618]. This is likely the reason that people don't participate in public health interventions.

In Mali, the number of qualified health personnel is inadequate throughout at all levels of the health system. It is also unequally distributed over the country (more specialized staff in the south than in the north). The same scenarios is observed for health infrastructure [1921 . The nomadic community pays a heavy price because of the population's lifestyle and the extent of the occupied region.

The most used means of transportation to reach the health center was a car in nearly $40 \%$ of cases. The cars used most often belong to the traders of the locality,
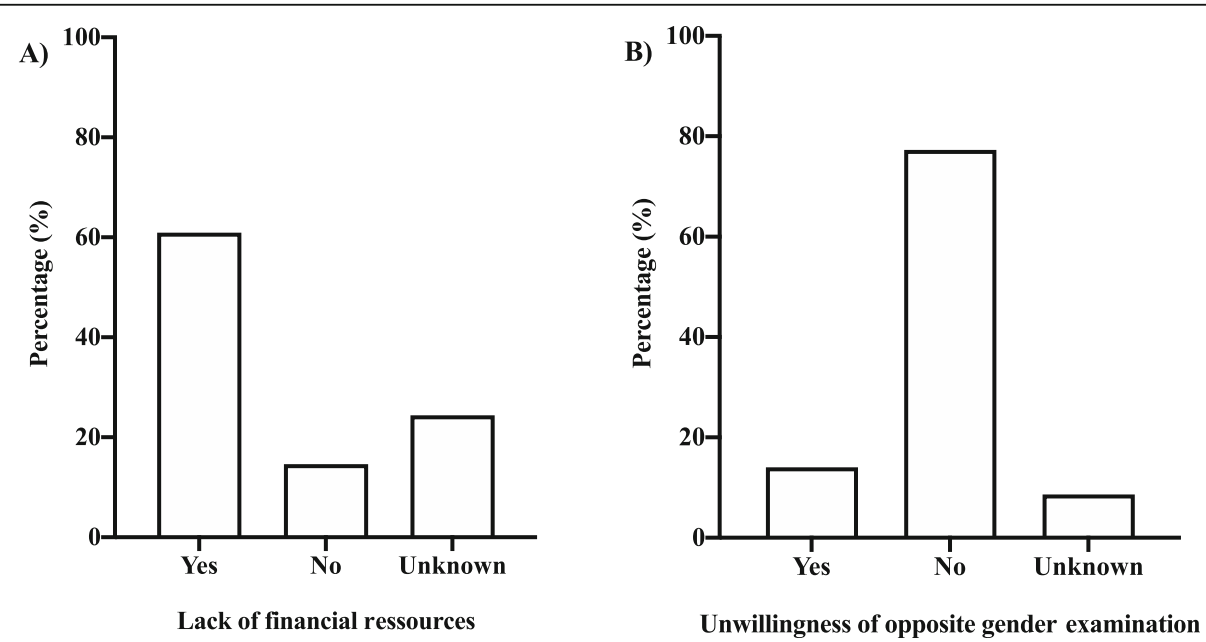

Fig. 3 Perception of respondents about the lack of financial resources and the unwillingness of opposite gender examination 
some high-ranking officials such as the mayor, members of parliament and tribal chiefs. Unfortunately, these cars are not available for the community members all the time. In addition, it is often necessary to be a close relative of the owner to be able to borrow the car. There are also some non-governmental organizations such as AVSF - Agronomes et Vétérinaires Sans Frontières (https://www.avsf.org/fr/posts/570/full/mali) that operate in these areas with mobile teams to give care [11]. The cars of these organizations could also be used if the opportunity lends itself to it. Distances from referral health centers are quite long. With the sand of the Malian desert the roads are inaccessible. This demonstrates the difficulties that the populations have with the means of transport in nomadic areas. All these centers are led by nurses of both genders' male and female except the health center of Gossi which is led by a physician. Furthermore, $41.15 \%$ of our study participants lived less than $5 \mathrm{~km}$ from the nearest health center. This short distance can be explained by the fact that the investigators were not able to go very far from the city of Ber which hosts a military camp. This was due to insecurity and to avoid exposure to attacks of any kind. The same situation was observed in Gossi. The cities of Gossi and Ebang imalane in the commune of Gossi, each have a health center provided by a mosque or church. Indeed, these services are available only to those who live near these centers. Very remote nomadic campsites have not been included because of the very limited means of transportation and also the insecurity.

In Ber, El Moctar et al. (2006) found that care is not available to all in this area. Indeed, those who have access to care are those who are essentially living near health centers and those with the means to ensure the costs of transportation and medicines. For others, going to the health center is difficult or even impossible because of poverty or the distance [22]. High transportation costs and the poor-quality of the roads remain one of the main barriers that limit access to health centers in this area. The long distances to health facilities and the unavailability of ambulances have exacerbated existing inequalities in access to quality care in the northern part of Mali [22].

Approximately, $39.04 \%$ of participants found that the cost of care was too expensive against $11.54 \%$ who thought that the cost of care was affordable compared to neighboring countries such as Burkina Faso or Algeria or Niger. However, there is also a cultural problem: many of these people have, cattle, and other animals but do not want to sell their animals for cash to pay for health needs. In 2006, El Moctar et al. found in Ber that $96.6 \%$ of people said they were ready to go to the health center if care was free [22]. Lack of money was cited as the main obstacle to access to health care among women respondents (53\%) [12]. Many studies reveal that the most vulnerable do not receive all necessary care when the needs are greater than elsewhere. Inequality in access to care is present almost everywhere in nomadic areas even in sedentary and nomadic communities. More than $63.26 \%$ of the study participants had an average monthly income lower than 120\$ USD. The cost of health care is a burden increasingly unbearable for the socially and economically vulnerable communities [11, 23, 24];:

Another factor cited was the use of traditional medicine, in which $44 \%$ of the participants visits first traditional healers and marabouts (people who use Quran verses to treat diseases) in case of illness. El Moctar et al. report that $57.4 \%$ of nomadic communities use traditional medicine first and modern medicine as an alternative. Although cost is important, this factor should not be overestimated in the analysis of the conditions of access to basic health services. Many studies have shown the link between improved quality and increased attendance within nomadic populations $[20,25,26]$.

Advanced strategy consists of offering to villages or neighborhoods far from the health facility a health care team that provides the necessary elements such as vaccinations, prenatal care, and education sessions for newborns. It makes it possible to reach people who cannot regularly travel to the health center. The advanced strategy generally covers localities 5 to $15 \mathrm{~km}$ from the community health center. Mobile strategy usually refers to health staff who travel from the community health center to provide health services to people living in remote areas or to mobile populations such as nomads. Mobile teams may travel for several days to reach targeted people. In Mali, this strategy is recommended beyond $15 \mathrm{~km}$. The two strategies are currently used to reach non-functional health areas and are often considered the best approach in nomadic areas. An evaluation made by AVSF reported that $84 \%$ of participants said that the actions of the joint mobile health component (human and animal health) were in line with their needs [27]. Furthermore, a lot of people would prefer a fixed health center for several reasons including cost, stability of personnel, health facilities, the short stays of the mobile team on-site, non-functionality of certain markets (weekly local markets), the lack of communication and community leadership. All these reasons make the above-mentioned approaches inappropriate for better access to health services. The data presented in this article will certainly have changed since the 2012 crisis, which is still ongoing and is exacerbate from day to day. We believe that access to care has become much worse than when we conducted this survey. We affirm this because immediately after our investigation, the military coup of 2012 occurred and the following year the whole north of Mali was invaded by terrorists. This remains 
the current state as we write this manuscript. All state services, including health services or health providers have left these regions.

Our study does have some limitations. First, the data are almost 10 years old, having been done in 2011. Nevertheless, we believe that these data are still valuable. Since we conducted this study, the health care services in northern Mali have not improved, primarily because of the coup of 2012, and secondly the Tuareg rebellion and the invasion of the country by terrorists. These conditions have disrupted health services. Today, health care services are almost non-existent in these districts where the data were collected. Reforms of the health sector are underway in Mali, but these reforms are not being implemented yet and certainly will not have any impact on the situation in the upcoming months. A new study is needed to assess health services and their accessibility by the nomadic populations 10 years after our study.

Second, the data may certainly contain information and selection bias. Some participants may have exaggerated the importance of the information just to get the investigators' attention, or they may have hidden cultural information such as household decisionmaking power that could be a significant barrier to access health care. In order to minimize these biases, we have explained the questions to the participants in a very precise manner in Kel Tamasheq the language of the study population, and also in French, the official language of Mali. Additionally, almost $80 \%$ of the interviewers were natives of the northern regions and ethnic groups, making them more familiar with the people and their culture.

Third, due to insecurity, we were unable to visit some areas of the study sites where there are large nomadic camps. If we had been able to visit, the information reported here could have been more important. The investigation teams (interviewers) were made up of two people (one man and one woman). In some remote areas, interview teams were made up of only men to protect their integrity ant to avoid cultural problems with regard to women's place in society. It is possible that some women would not have felt comfortable speaking with them during the study, so this is an additional limitation to our research.

Finally, we should have developed multivariate models since we are talking about factors that hinder access to health care. Unfortunately, the design of this study did not allow us to collect data to do the modeling. The primary goal of this study was not to identify risk factors but to explore the field to see how the communitydirected interventions process could be implemented. It should also be noted that this study is part of a larger study. Future studies should include these aspects in their design.

\section{Conclusion}

On completion of the study, it appears that despite the efforts from the Malian government and its health partners, access to basic health interventions is not meeting expectations in nomadic areas. This study shows the importance of a set of factors that should be considered to improve access to health interventions in nomadic areas. These factors include the underutilization of health services, quality of services offered, the attachment to ancestral nomadic values, poverty, gender and the current strategies recommended by health policies. However, nomads are interested in all strategies that will allow them to participate in the management of their health problems.

\section{Abbreviations}

ADESAH: Association pour le Développement Endogène au Sahel AVSF: Agronomes et Vétérinaires Sans Frontières; CHW: Community Health Workers; NGO: Non-Governmental Organization; PMA: Minimal Package of Activities; SPSS: Statistical Package for Social Sciences; USD: United States Dollar

\section{Supplementary Information}

The online version contains supplementary material available at https://doi. org/10.1186/s12889-021-10481-w.

Additional file 1. Questionnaire. List of questions that were used to collect the data.

\section{Acknowledgements}

We would like to address special thanks to the local healthcare staff of Timbuktu (Ber) and Gourma Rharous (Gossi), the villagers and all the participants for their cooperation and participation to the study activities. We also would like to thank Dr. Alison Krentel from the Bruyère Research Institute / University of Ottawa for reviewing the manuscript.

Authors' contributions

The study was designed and conceived by MS, YIC, SYC, HD, AAS, YAR, SFT, WRB, TD, SD1 and SD2; data were collected by MS, YIC, SYC, HD, SFT, AAS, YAR, DWM, FWA and SD2; data processing and analysis and manuscript drafting were performed by MS, YIC, SYC, HD, KMA, AFD, MT, MD, SD1, and SD2; and the final version of the manuscript was approved by MS, YIC, SYC, HD, SFT, WRB, SD1, and SD2. All authors read and approved the final version.

\section{Funding}

The study was supported by the UNICEF/UNDP/World Bank/WHO Special Program for Research and Training in Tropical Diseases (TDR) (No A90361) granted to YIC and the Faculty of Medicine and Odontostomatology of Bamako. Funders have no role in the study design, data collection, analysis and interpretation or the decision to write the manuscript.

Availability of data and materials

The datasets generated and analyzed during this study are presented in Tables 1, 2, and 3 and Figs. 1 and 2. Additional information is available from the authors upon reasonable request.

\section{Declarations}

Ethics approval and consent to participate

The ethics approval was obtained from the ethical committee of the Faculty of Medicine, Pharmacy and Odonto-Stomatology of Bamako (N010-42- 
FMPOS). Investigators obtained individual written informed consent from all the study participants. Information was anonymous and treated as confidential.

\section{Consent for publication}

Not applicable.

\section{Competing interests}

The authors declare that they have no competing interests.

\section{Author details}

'Mali International Center for Excellence in Research (ICER), University of Sciences, Techniques, and Technologies of Bamako (USTTB), Bamako, Mali. ${ }^{2}$ Interdisciplinary School of Health Sciences | Faculty of Health Sciences, University of Ottawa, 75, av. Laurier Est, Ottawa ON K1N 6N5, Canada. ${ }^{3}$ General Directorate of Health and Public Hygiene, Ministry of Health and Social Affairs of Mali, Bamako, Mali. ${ }^{4}$ World Health Organization (WHO), Regional Office for Africa, Cite du Djoue, PO Box 06, Brazzaville, Congo. ${ }^{5}$ Department of International Health, Health System Program, The Johns Hopkins Bloomberg School of Public Health, Baltimore, MD 21205, USA.

\section{Received: 2 March 2020 Accepted: 22 February 2021}

Published online: 28 February 2021

\section{References}

1. Cellule de Planification et de Statistique (CPS/SSDSPF), Institut National de la Statistique (INSTAT/MPATP),INFO-STAT et ICF International. Enquête Démographique et de Santé au Mali 2012-2013. Rockville: CPS, INSTAT, INFO-STAT et ICF International; 2014.

2. Keïta M. Typologie urbaine et accessibilité géographique potentielle des établissements de santé dits «modernes» dans le district de Bamako (Mali). Espace populations sociétés. 2018.

3. Konaté MK, Kanté B, Djenepo F. Politique de santé communautaire et viabilité économique et sociale des centres de santé communautaires au Mali; 2003.

4. $\quad$ Benoist (Joseph Roger de) : Le Mali. — Paris, L'Harmattan, 1989. pp. 297298.

5. Diop M, Revenga A, Fajnzylber P, Hoogeveeen J, Etang-Ndip A, Sanoh A, et al. Évaluation de la situation socio-économique des populations du nord Mali et leurs priorités.1998.

6. Diarra S, Cissé P. Migrations et pauvreté au Mali. Questions de population au Mali Bamako: Le Figuier/UNFPA; 2003. p. 203-26.

7. Aliou S. What health system for nomadic populations. World health forum 1992:13(4):311-4.

8. Sangaré MB. Accès aux Soins de Santé des Communautés en Milieu Nomade, Cas des Communes de Ber et Gossi à Tombouctou au Mali [Thèse de médecine $\mathrm{N}^{0}$ 12M85]. Bamako: Faculté de médecine, de pharmacie et d'odontostomatologie; 2012. 100.

9. Ahmed MAA, Hamelin-Brabant L, Gagnon M-P. Nomads' perceptions of quality, accessibility, and affordability of health services as determinants of using skilled birth attendants in Gossi. Mali Midwifery. 2019;79:e102556.

10. Sheik-Mohamed A, Velema JP. Where health care has no access: the nomadic populations of sub-Saharan Africa. Tropical Med Int Health. 1999; 4(10):695-707.

11. Abakar MF, Schelling E, Béchir M, Ngandolo BN, Pfister $K$, Alfaroukh IO, et al. Trends in health surveillance and joint service delivery for pastoralists in West and Central Africa. The future of pastoralism (J Zinsstag, E Schelling \& B Bonfoh, eds). Rev Sci Tech Off Int Epiz. 2016;35(2):683-91.

12. Ag Ahmed MA. Des agents de santé communautaires pour la promotion de la santé des pasteurs nomades au Mali. Glob Health Promot. 2016;23(4): 80-4.

13. Sangare MB, Coulibaly YI, Souleymane AA, Rissa YA, Moussa DW, Abdallah FW,et al.: Nomads access to the current healthcare system is impaired by their perception of its cost, quality, accessibility and by gender segregation in Timbuktu, Mali [Abstract]. 60th annual meeting of the American Society of Tropical Medicine and Hygiene, December 4-8, 2011, Philadelphia, PA, USA. [cited 2021 Feb 17]; No. 1104; P. 1001-1250. Available from: https:// www.astmh.org/ASTMH/media/Documents/Abstracts1001-1250.pdf

14. Wyss: Réflexions pour une meilleure prise en charge... - Google Scholar [Internet]. [cité 19 déc2019]. Disponible sur: https://scholar.google.com/ scholar_lookup?hl=en\&publication_year=2000\&pages=1429\&author=M+
Wiese\&title $=$ R\%C3\%A9flexions+pour+une+meilleure+prise+en+charge+de+ a+sant\%C3\%A9+en+milieu+nomades+au+Tchad.

15. Carpenter CJ. A meta-analysis of the effectiveness of health belief model variables in predicting behavior. Health Commun. 2010;25(8):661-9.

16. Balique H, Ouattara O, Iknane AA. Dix ans d'expérience des centres de santé communautaire au Mali. Sante Publique. 2001;13(1):35-48.

17. Balique $\mathrm{H}$. Le concept de communauté et ses limites: à propos des centres de santé communautaires du Mali. In: Communication au Colloque «Anthropologie des systèmes et des politiques de santé», organisé à Paris par l'Amades 2001. 7(8): e016558.

18. Iknane AA, Balique H, Diawara A, Konate S, Niangaly A, Thiero TA, et al. La santé communautaire au Mali: Acquis, enjeux et perspectives après deux décennies de mise en oeuvre. Mali Santé Publique. 2011;1(1):40-8.

19. HFG Project. Évaluation du Système de Santé au Mali [Internet] Gouvernement et associations à but non lucratif. [cité 16 déc 2019]. Disponible sur: https://fr.slideshare.net/HFGProject/valuation-du-systme-desant-au-mali.

20. Coulibaly L. Etude sur la sous fréquentation des CSCOM dans la région de Koulikoro (Mali) [Thèse de médecine N 05M210]. Bamako: Faculté de médecine, de pharmacie et d'odontostomatologie; 2010. 132.

21. Deville C, Hane F, Ridde V, Touré L. La Couverture universelle en santé au Sahel: la situation au Mali et au Sénégal en; 2018.

22. Mohamed E-M. Logique de production et utilisation des services de santé en milieu nomade au Mali: cas de la commune de Ber (Tombouctou) [Thèse de médecine $N^{0}$ 06M269]. Bamako: Faculté de médecine, de pharmacie et d'odontostomatologie; 2006. 147.

23. Okeibunor JC, Onyeneho NG, Nwaorgu OC, I'Aronu N, Okoye I, Iremeka FU, et al. Prospects of using community directed intervention strategy in delivering health services among Fulani Nomads in Enugu State, Nigeria. International Journal for Equity in Health. 8 avr. 2013;12(1):24.

24. Ahmed MA, Hamelin-Brabant L, Gagnon MP. Sociocultural determinants of nomadic women's utilization of assisted childbirth in Gossi, Mali: a qualitative study. BMC pregnancy and childbirth. 2018;18(1):388.

25. Doumbouya ML. Accessibilité des services de santé en Afrique de I ' Ouest : le cas de la Guinée. HAL. 2008:18(2):1-18.

26. Després $C$, Dourgnon $P$, Fantin $R$, Jusot $F$. Le renoncement aux soins : une approche socio-anthropologique, vol. 8; 2011

27. Ndiaye P, Lecomte P. La gestion durable des parcours dans le Sahel: Stratégies, Pratiques, Gouvernance et Promotion. Note de cadrage de la première édition des entretiens techniques du PRAPS; 2016.

\section{Publisher's Note}

Springer Nature remains neutral with regard to jurisdictional claims in published maps and institutional affiliations.

Ready to submit your research? Choose BMC and benefit from:

- fast, convenient online submission

- thorough peer review by experienced researchers in your field

- rapid publication on acceptance

- support for research data, including large and complex data types

- gold Open Access which fosters wider collaboration and increased citations

- maximum visibility for your research: over $100 \mathrm{M}$ website views per year

At $\mathrm{BMC}$, research is always in progress.

Learn more biomedcentral.com/submissions 